\title{
Effect of Detergent Use on Water Quality in Rewa City of M.P. (India)
}

\author{
${ }^{1}$ Dr. Vinod Dubey, ${ }^{2}$ Neha Singh, ${ }^{3}$ Shalini Singh, ${ }^{4}$ Archna Shukla, \\ ${ }^{5}$ Aparna Pandey \\ ${ }^{l}$ Professor, Applied Chemistry Division, Deptt. Of Chemistry, S.G.S. Govt. P.G. Autonomous (NAAC \\ Accredited) College, SIDHI-486661 (M.P.) India \\ ${ }^{2,3,4}$ Research Scholar, Applied Chemistry Division, Deptt. Of Chemistry, S.G.S. Govt. P.G. Autonomous (NAAC \\ Accredited) College, SIDHI-486661 (M.P.) India \\ ${ }^{5}$ M.Sc. Student of Deptt. Of Chemistry, S.G.S. Govt. P.G. Autonomous (NAAC Accredited) College, SIDHI- \\ 486661 (M.P.) India
}

\begin{abstract}
With the existing and projected population growth the detergent uses are increasing which are becoming one of the important cause behind the all type of pollution along with the other pollutant which are as a waste material discharged due to various human activities. By analyzing the various water sample taken from the river/ponds and other water bodies of the study area and the final result so obtained clearly indicate that the detergent being used are having sufficient amount of synthetic chemicals. Surfactant like (ABS) Alkyl benzene sulfonate and (LBS) linear Alkyl benzene Sulfonate and certain phosphate. Various detergent analysis which are substantially responsible for surface/ground water pollution, in the city area. Along with pollution these surfactant are also creating procedural problem during waste water treatment. This research work is to reveal the reason behind the problem and to way out from the problem.
\end{abstract}

Key words: Waste Water, Detergent, Foaming, Surfactant, Pollution.

\section{Introduction}

The city Rewa is located on north east part of eastern M.P. having two rivers Bichhiya and Behar and one main pond/talab named Rani Talab located in the heart of city. The Bank of river Bichhiya and Behar accommodates larger part of city dwellers. The municipal area of city comprises 45 administrative ward and cover the area of 6927 hectare and having population of 235422 with a projected population growth of 4 to 5 percent yearly. Industrial development in Rewa city is increasing day by day apart from this being a divisional head quarter of the administration various educational institute of learning of higher education in all field, the influx of families from surrounding area are also considerably increasing. Before the reorganization of the state Rewa was the capital of Vindhya State, hence this city is historically and religiously important for the people of Vindhya region.

Hence due to industrial development and population growth, the rivers pond, talab and other urban surface water are becoming more and more polluted. Meanwhile, the detergents are also playing an important role toward enhancing pollution. Detergent in waste water comes from residence in the form of household detergent, agriculture runoff in the form of herbicides and insecticides and from certain industries.

Rewa city does not have proper drinking water treatment and supply system. Tap water and public water sources are generally contaminated but still essential, and those without other resources rely on local surface water mainly the Bichhiya and Bihar River/Rani talab for bathing washing, drinking and as a public toilet. Furthermore the River and Pond/talab has become a sewage discharge site for municipal waste water and industrial dumping ground for local business with no other means of disposal.

\section{Result and Discussion}

Water sample analysis has been done on monthly basis (from period July 11, to June 12) three locations each along the banks of both river, and Rani talab have been fixed for taking sample throughout the year. The analysis done using standard method obeying WHO water quality Parameters as well (see table 1). 
Effect of Detergent use on Water Quality in Rewa City of M.P. (India)

Table 1 : Showing average value of all parameter of water analysis report of Rewa City

\begin{tabular}{|c|c|c|c|c|c|c|c|c|c|}
\hline & \multicolumn{3}{|c|}{ Bichhiya River } & \multicolumn{3}{|c|}{ Beehar River } & \multicolumn{3}{|c|}{ Rani talab } \\
\hline Site $\longrightarrow$ & S-1 & S-2 & S-3 & S-4 & $\mathrm{S}-5$ & S-6 & S-7 & $\mathrm{S}-8$ & S-9 \\
\hline $\mathrm{DO}(\mathrm{mg} / \mathrm{L})$ & 4.82 & 3.74 & 10.22 & 2.52 & 1.85 & 7.96 & 6.19 & 7.65 & 9.11 \\
\hline TDS (g/L) & 0.22 & 0.36 & 0.39 & 0.23 & 0.26 & 0.16 & 0.36 & 0.29 & 0.38 \\
\hline $\mathrm{PH}$ & 6.2 & 6.5 & 7.1 & 7.3 & 6.3 & 6.2 & 6.8 & 6.9 & 7.8 \\
\hline Turbidity NTU & 200 & $>100$ & 200 & $>100$ & $>100$ & $>100$ & 400 & 500 & 300 \\
\hline $\mathrm{NO}_{3}(\mathrm{mg} / \mathrm{L})$ & 5.17 & 6.00 & 3.39 & 1.89 & 2.42 & 10.00 & 12.92 & 25.00 & 30.00 \\
\hline $\mathrm{PO}_{4}(\mathrm{mg} / \mathrm{L})$ & 0.50 & 0.43 & 0.32 & 1.39 & 0.76 & 0.06 & 0.39 & 0.52 & 0.42 \\
\hline TSS (mg/L) & 376 & 538 & 185 & 148 & 78.0 & 100.00 & 336 & 566 & 222 \\
\hline $\mathrm{BOD}(\mathrm{mg} / \mathrm{L})$ & 90 & 50 & 69 & 42 & 23 & 17 & 151 & 238 & 170 \\
\hline $\mathrm{COD}(\mathrm{mg} / \mathrm{L})$ & 190 & 112 & 71.01 & 72.8 & 27.2 & 19.9 & 275 & 312 & 256 \\
\hline
\end{tabular}

For the overall water pollution of the study area the main reason responsible are the problem of foaming and it is entirely arising from the use of synthetic detergent.

The another main problem behind the overall water pollution are the foaming in surface water as well as in waste water treatment plants (WWTP) and it is arising entirely due to frequently use of synthetic laundry detergent and as well as other synthetic detergent as a cleanser used by whole of the population. The microorganisms present in the waste water are also responsible for foaming (see table 2).

Table 2: Showing WWTP Performance

\begin{tabular}{|c|c|c|c|}
\hline Parameter & Influent & Effluent & Removal \\
\hline $\mathrm{BOD}$ & $278 \mathrm{mg} / \mathrm{L}$ & $26 \mathrm{mg} / \mathrm{L}$ & $90 \%$ \\
\hline $\mathrm{COD}$ & $1100 \mathrm{mg} / \mathrm{L}$ & $240 \mathrm{mg} / \mathrm{L}$ & $75 \%$ \\
\hline $\mathrm{TSS}$ & $210 \mathrm{mg} / \mathrm{L}$ & $102 \mathrm{mg} / \mathrm{L}$ & $52 \%$ \\
\hline $\mathrm{TKN}$ & $45 \mathrm{mg} / \mathrm{L}$ & $25 \mathrm{mg} / \mathrm{L}$ & $35 \%$ \\
\hline $\mathrm{NH}_{4}-\mathrm{N}$ & $42-3 \mathrm{mg} / \mathrm{L}$ & $21.9 \mathrm{mg} / \mathrm{L}$ & $45 \%$ \\
\hline $\mathrm{P}$ & $7.2 \mathrm{mg} / \mathrm{L}$ & $3.2 \mathrm{mg} / \mathrm{L}$ & $50 \%$ \\
\hline
\end{tabular}

Analysis of detergents for total anionic surfactants was performed where estimated detection limit range from $0.002 \mathrm{mg} / \mathrm{L}$ to $0.275 \mathrm{mg} / \mathrm{L}$ anionic surfactant using a $\operatorname{Hach}^{(\mathrm{R})}$ DR 2010 spectrophotometer. Following diagram illustrate the total anionic surfactant concentration in the detergent (Powder form) taken for the study.

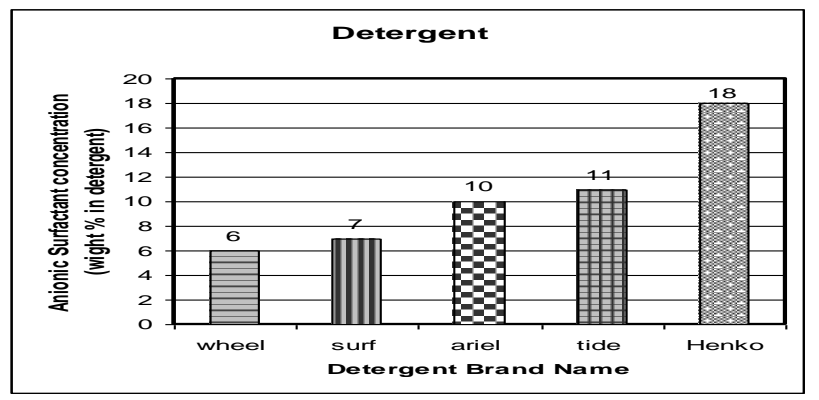

The finding of the analysis clearly reveals that the main anionic surfactants are (ABS) Alkyl benzene sulfonate and Linear alkyl benzene sulfonate (LAS) and Phosphate concentrations responsible for foaming problem in WWTP and in surface water too.

The anionic surfactant like ABS is poorly degradable while LAS is degradable and the manufactures mostly uses the ABS because of its more cleaning ability and less expensive. But these surfactants are responsible for overall pollution. At preset due to harmful effect of ABS surfactant its uses has been banned by developed countries.

The flow rates of Rivers has also bee taken into account while reaching at certain result because of the concentration of various pollutant differs throughout the year.

Table 1 shows high value of D.O. $10.22 \mathrm{mg} / \mathrm{L}$ at the site $\mathrm{S}-3$ followed by 9.11 and 7.96 at site $\mathrm{S}-9$ and S-6 high value of T.D.S. $0.39 \mathrm{~g} / \mathrm{L}$ at site S-3. PH ranges from 6.2 to 7.8 . turbidity highest 500 at S-8, lowest 100 at S-2, S-4, S-5, S-6, Concentration of Nitrate $\left(\mathrm{NO}_{3}\right)$ highest $30.00 \mathrm{mg} / \mathrm{L}$ at S-9 followed by $2500 \mathrm{mg} / \mathrm{L}$ at S-8 and minimum $1.89 \mathrm{mg} / \mathrm{L}$ at $\mathrm{S}-4, \mathrm{PO}_{4}$ high $0.76 \mathrm{gm} / \mathrm{L}$ at S-5 minimum $0.43 \mathrm{mg} / \mathrm{L}$ at S-2 the highest value of TSS $566 \mathrm{mg} / \mathrm{L}$ at S-8 minimum $100 \mathrm{mg} / \mathrm{L}$ 5.6. BOD higher $238 \mathrm{mg} / \mathrm{L}$ at S-8 followed by 170 at S-9, 151 at S-7, COD highest 312 at S-8 followed by 275,256 at S-7 and S-9. 
The above statistics clearly shows that the water of the Rewa city is polluted but the extent of pollution differs site to site, within the city.

Table 2, it shows that the waste water/material taken into treatment plant having sufficient amount of waste material which are solely responsible for the pollution.

The Diagram shows clearly that the detergent powder being used are having sufficient amount of surfactant ranges mainly from $6 \%$ to $10 \%$ highest $18 \%$ with the Hanko detergent powder, which are responsible to create foaming problem in WWTP and in surface water. The microorganism exist in the polluted water is due to the presence of oil and grease in the industrial waste materials are also responsible with the surfactant of the detergent for creating foaming due to their chemical interactions. The phosphate concentration added in the detergent due to its cleansing ability is also plays are important role in creating foaming problems.

\section{Conclusion}

Table 1, 2 and diagram clearly indicate the different related average status of the polluted water which clearly reveals that the water of the both river as ponds/ talab of the Rewa city is polluted due to -

1. Discharge of industrial waste/other waste material by municipalities along the bank of river and pond/talab.

2. Use of synthetic laundry detergent along the bank of river/ponds.

3. Use of detergent/soap etc. as a cleanser by whole the population.

4. Insecticides/pesticides (which contain the chemicals as in detergents) come through runoff water during raining season from surrounding agriculture fields.

The findings of this research projects (case study) clearly hint that the use of ABS synthetic surfactant in the detergent should be banned and disposal of all type of waste material should be scientifically planned.

\section{Experiment}

The whole study was under study through out the year including all season and sample taken from different site for the analysis. The analysis of the water sample done as per the standard analytical methods for the various parameters illustrated in table- 1 . The thresholds limit for various parameters has been consistent according to the WHO norms fixed for. The detergent analysis has been done using spectrophotometer by making various sample solutions various detergent with various water of the study area.

\section{Reference :}

[1]. Arata, Tetsuji, "Waste water in the Greater Kathmandu" Japan Association of Environment and Society for the $21^{\text {st }}$ century, March 2003

[2]. Barber, L. and J. Leenheer, "Organic Contamination of the Mississippi River from municipal and industrial waste water http://water.usgs.gov/pubs/circ/cire 1133/organic/html, 1995

[3]. Eichhorn, P. and M.E. Flavier, "Occurrence and fate of linear and branched ABS and their metabolites in surface water in the Philippines, The Science of the total Environment 269 (2001) pp- 75-85

[4]. Khanal, A. B. and B. Paudel and N. B. Khanal, "Operational Problems in the Bagmati sewage Treatment Plant", Development Insight, August-October 2002

[5]. Petrovic, Mira and Amadeo Rodrigez-Alba, "Occurrence and distribution of Nonionic surfactant their degradation Product and Linear Alkyl benzene sulfonate in coastal water and sediments in Spain', Environmental Toxicology and Chemistry, Vol. 21, Issue 1, pp-37-46 (2002)

[6]. Sandia National Laboratories, "South Asia Environmental Monitoring Project" http://sa-env.cmc.sandia.gov/undated

[7]. Shakya Suman K., "Alarming Trend's of River pollution in Kathmandu Nepal" A Journal of the environment, volume 6, Number 7 (2001)

[8]. SoapandDetergent Association (SDA) cleaning products over view, http://www.sdahg.org/cleaning/soaps and detergent, html, June, 15,1999 